\title{
CONTENTS OF VOLUME 25
}

R. S. ANDERSSEN and D. R. JACKETT: Linear functionals of foliage angle density

K. BANER.JEE: See J. R. GUPTA

M. B. BANERJEE: See J. R. GUPTA

J. M. BARRY, J. H. JENKINSON and J. P. POLLARD: A discrete Fourier analysis of coarse mesh rebalancing and some associated iterative methods

N. G. BARTON: An asymptotic theory for dispersion of reactive contaminants in parallel flow

L. BASS, A. J. BRACKEN and R. VYBORNY: Minimisation problems for implicit functionals defined by differential equations of liver kinetics

A. R. BESTMAN: Low Reynolds number flow in a heated tube of varying section

M. A. BOX: See B. H. J. McKELLAR

A. J. BRACKEN: See L. BASS

A. BROWN: Solutions of period three for a non-linear difference equation

P. J. BRYANT: Cyclic gravity waves in deep water

451

V. T. BUCHWALD: See F. VIERA

PETER L. CHESSON: Infinitely divisible random transition probabilities with application to dependent Markov chains

E. J. COLMAN: See R. J. SOBEY

B. D. CRAVEN, B. MOND and J. PARIDA: On a complementarity problem associated with nondifferential programming

DAVID ELLIOTT: A Galerkin-Petrov method for singular integral equations

C. B. FANDRY, R. L. HUGHES and L. M. LESLIE: Stationary waves forced by topography in a vertically sheared, stratified rotating fluid

K. GOPALSAMY: Harmless delays in a periodic ecosystem

K. GOPALSAMY: Delayed responses and stability in two-species systems

J. R. GUPTA, S. K. SOOD, R. G. SHANDIL, M. B. BANERJEE and K. BANERJEE: Bounds for the growth of a perturbation in some double-diffusive convection problems

J. F. HARPER: Axisymmetric Stokes flow images in spherical free surfaces with applications to rising bubbles

R. L. HUGHES: The anti-cyclonic shear wave: a new geophysical wave

R. L. HUGHES: See C. B. FANDRY

R. R. HUILGOL, R. JANUS, M. A. LOHE and T. W. SAG: On the application of a numerical algorithm for Hopf bifurcation to the hunting of a wheelset

N. T. HUNG and S. A. MASLOWE: Interaction of internal waves in a continuous thermocline model

D. R. JACKETT: See R. S. ANDERSSEN

R. JANUS: See R. R. HUILGOL

J. H. JENKINSON: See J. M. BARRY

R. S. JOHNSON: The propagation of small amplitude long waves on the surface of superfluid helium 
R. B. LEIPNIK: On Charwat's theory of motion of tracers in planar vortex flows

L. M. LESLIE: See C. B. FANDRY

M. A. LOHE: See R. R. HUILGOL

E. R. LOVE: See B. H. J. McKELLAR

S. A. MASLOWE: See N. T. HUNG

B. H. J. McKELLAR, M. A. BOX and E. R. LOVE: Inversion of the Struve transform of half integer order

JOHN W. MILES: Surface-wave interaction with a deeply submerged circular duct

B. MOND: See B. D. CRAVEN

J. PARIDA: See B. D. CRAVEN

D. H. PEREGRINE: Water waves, nonlinear Schrödinger equations and their solutions

J. P. POLLARD: See J. M. BARRY

M. REZAYAT, F. J. RIZZO and D. J. SHIPPY: A unified boundary integral equation method for a class of second order elliptic boundary value problems

P. F. RHODES-ROBINSON: On the generation of water waves at an inertial surface

N. RLAHI: On nonlinear overstable convection rolls in a rotating system

F. J. RIZZO: See M. REZAYAT

T. W. SAG: See R. R. HUILGOL

W. SARLET: Symmetries and the inverse problem of Lagrangian dynamics for linear systems

R. G. SHANDIL: See J. R. GUPTA

D. J. SHIPPY: See M. REZAYAT

R. J. SOBEY and E. J. COLMAN: Scattering analysis and synthesis of wave trains

S. K. SOOD: See J. R. GUPTA

K. L. TEO: See K. H. WONG

E. O. TUCK and J.-M. VANDEN BROECK: A cusp-like free-surface flow due to a submerged source or sink

J.-M. VANDEN BROECK: See E. O. TUCK

F. VIERA and V. T. BUCHWALD: The generation of surface waves by an intense cyclone

R. VYBORNY: See L. BASS

K. H. WONG and K. L. TEO: A conditional gradient method for a class of time-lag optimal control problems

W. W. WOOD: Energy intensity of inertial waves in a sphere 